\title{
CURRENT SCENARIO OF BUILDING-INTEGRATED PHOTOVOLTAICS (BIPVS)
}

\author{
Ashish kumar ${ }^{1 *}$ and Dr. J.P. Kesari ${ }^{2}$ \\ ${ }^{*}$ M. Tech (RET-Renewable Energy Technology), Delhi Technological University (formerly DCE), Delhi \\ ${ }^{2}$ Former AICTE Director \& Associate Professor, Delhi Technological University (formerly DCE), Delhi
}

\section{*Corresponding Author: -}

\begin{abstract}
: -
The building-incorporated photovoltaics (BIPVs) are photovoltaic (PV) materials that are used to supplant traditional/conventional building materials that are being used in construction of building covering, for instance, the roof tiles, front windows, or veneers. Further, they represent a strong, versatile and eco-friendly means for attaining the goal of ever-increasing power demand for zero energy and zero emission buildings of the adjacent future. In this regard, BIPVs may offer an aesthetically pleasing, cost-effective and real-world solution, to integrate photovoltaic solar cells (BIPVs) reaping solar radiationto produce electricity along with climate protection of the buildings. This research work précises thecurrent stage of the development in the Building-integrated Photovoltaic systems and the scope of future research in building integration of photovoltaics, incorporating the latest and innovational ideas and features of BIPVs which include BIPV tiles\& modules, BIPV foils, and solar power cell glazing products.
\end{abstract}

Keywords: - Building-integrated photovoltaic;Eco-friendly; Zero energy; Zero emission; BIPVs; Solar cell; Recent development.

\section{(c) $($ ) (1)}




\section{INTRODUCTION}

As it is one of the well-known facts that the world's energy demand is increasing like a rapid fire, this exponential increase in energy demand in the name of development and to raise the living standard of humanity, a stage has arrived where focus should be on renewable \& non-polluting energy, along with high energyefficiency and cost effectiveness. Buildings should be designed onzero energy and zero emission concept. In order to make any building complied to the idea/concept of zero energy and zero emission, it is required to cropits energydemands from itssurroundings itself, where solar energy from the sun seems to be one of the major available options. BIPV systems are the energy systems where solar cells are embedded within the climate coverings of buildings and these solar cells exploitsolar radiation to generate electricity at justifiedrunning/maintenance cost, and represent a stronger and adaptablemeans for attainingthe goalsof clean, ecofriendly and renewable energy w.r.t aesthetical, cost-effective and real- world technical solutions.

BIPV systems can offerdual savings i.e., they reduce materials as well as electricity expenses. Also, they lead to lesser usage of fossil fuels and lower emission of ozone depleting gases (CFCs etc.), and alsoenhance architectural attractiveness of the building. Further, the building-integrated photovoltaic (BIPV) systems mayreplace the traditionally used building materialsand systems within the climate casing of buildings, for instance, the roofs, skylights and frontages. BIPV frameworks should be considered as a utilitarian part of the building structure as they are structurally coordinated into the building's configuration [3]. Hence, the BIPVs servesthe dual functionality of beinga building envelope material and also work asa power generator [4].

This research work essentiallyconcludes the current scenario of the developments of BIPVs, including the BIPV tiles, foils,modules andsolar (PV) cell glazing products, but we have also focused on building- attached photovoltaic (BAPV) systems because of their similarity with BIPVs. Building-applied photovoltaics (BAPV) are sometimes referred as photovoltaics that arefitted into the buildingenvelope onlyafter construction workof the building is complete.For auxiliaryoverview and embellishments including some possible research prospects andconduits for the future BIPVs, reference [5] may be referred.

\section{Building integration processof photovoltaic (PV) cells}

First of all, the probable spaces within the building envelop have to be recognized for the integration of PV cells/modules. The building integration of photovoltaic (PV) cells are basicallydoneon slanted roofs, level roofs, fronts andsolar shielding systems. Building-integrated photovoltaic cells may be installed above the building envelope itself or onto the existingconventional rooftop or wall coveringsystems. These systems replace the building's outer envelope membrane, therefore serving simultaneously as a climate screen as well as a power source by generating electricity. Hence, BIPVs provide savings inmaterials and reduce labor as well, further reduce the electricity expenses. However, the Buildingintegrated photovoltaics (BIPVs) function as theclimate shelter screens which requires to have satisfactory or strict necessities of raintightness, toughness and durability.

Manyaspects have to be taken and evaluated w.r.t the integration of photovoltaic cells into theouter casing of building envelope. One of the important aspect is to ensure proper air gap below the PV cells in order to provide sufficient air flow which will reduce the temperature of the solar PV cells, because at high temperature theefficiency of the solar cells decreases, specifically for mono crystallineand poly crystalline silicon ( $\mathrm{Si}$ ) cells. Other aspect that hasto be considered is the leaning of the BIPVs, for both existing and new buildings, as PVcells essentially need to followthe inclination of roof (or the wall) for its proper integration in the buildings.Also the geographical position, orientation towards the sun and exposure area are yet another factors to beconsidered during integration process of the BIPV systems. Some BIPV companies also offer a range of dummymodules to deliver more aesthetical and reliable appearance of the rooftops and frontages.

Henceforth, it is concluded that BIPVs have to fulfil all the necessities, w.r.t different properties, of thebuilding's envelope membraneswhich they are substituting. Along the above explained factors, other building physical subjects like e.g. moisture and heat transportation in the building's envelope are also important and should be accounted for. Solar cell (PV) glazingproducts also offer a good solution for using the fenestration w.r.t sunshine, solar-heat gain, solarshading, and finally solar energy gain by transforming solarradiation into useful electrical energy.

\section{BIPV's architectural traits}

BIPV systems serve not only to create architectural appeal,they also offer savings in building materials that would otherwise be used and reduced electricity costs. Along with this, these systems will protect against the weather and will be a source of clean, eco-friendly and renewable energy.In view of availability, numerous options forinnovative architectural design are available with us provided by leading manufacturers of BIPVs, which are also aesthetically soothing. BIPVs may also be utilized as screeningdevices and also give a solution for semi-transparent elements of fenestration [10].

Further, silicon tilescan be used to construct a building-integrated photovoltaic roof which mayappear very much similar to a standard/conventional tiled roof, whereas semi-transparent modules can also beused infrontages or on the glass ceilings to craft different soothing visual effects.Some wants BIPV roofs to give clear visual impression and is preferred by mostof the architects, whileother people want the BIPV roofs to appear very much similar toa traditional/conventional roof.More info aboutbuilding integration ofphotovoltaicpower systems and building integration of BIPVs inparticular, may be found in references [3] [7]. 


\section{Test methods and BIPV quality standards}

Assessment/quality inspection of BIPVs involve several mathematical deciding factors, e.g. solar cell efficiency

$$
\eta=\mathrm{P}_{\max } /(\Phi \mathrm{A})
$$

where $\Phi$ is the input solar radiation in $\mathrm{W} / \mathrm{m}^{2}$;

$\mathrm{A}$ is the surface area of photovoltaic cell in $\mathrm{m}^{2}$;

$\mathrm{P}_{\max }$ is the power at maximum power point (MPPT) in Wor Watt-peak (Wp); $\mathrm{V}_{\mathrm{oc}}$ is the open circuit potential or voltage in volt $(\mathrm{V})$;

$\mathrm{I}_{\mathrm{sc}}$ is the short circuit electrical current in Amp (A);

Also,

$$
\text { Fill factor(FF) }=\mathrm{P}_{\max } /\left(\mathrm{V}_{\mathrm{oc}} \mathrm{I}_{\mathrm{sc}}\right)=(\mathrm{VI})_{\max } /\left(\mathrm{V}_{\mathrm{oc}} \mathrm{I}_{\mathrm{sc}}\right)
$$

The fill factor (FF), is a parameter which when combined with $\mathrm{V}_{\mathrm{oc}}$ and $\mathrm{I}_{\mathrm{sc}}$, governs the amount of power obtainablefrom a solar photovoltaic (PV) cell. Mathematically, it may be defined asthe ratio of the maximum powerobtainable from the photovoltaic solar cell to the product of $\mathrm{V}_{\mathrm{oc}}$ and $\mathrm{I}_{\mathrm{sc}}$. The significance of fill factor is that it measuresthe square-ness of the solar cell in terms ofthe area of the largest possible rectangle which can accommodate into the I-V characteristic curve of the photovoltaic cell. The graph representing the fill factor is given below.

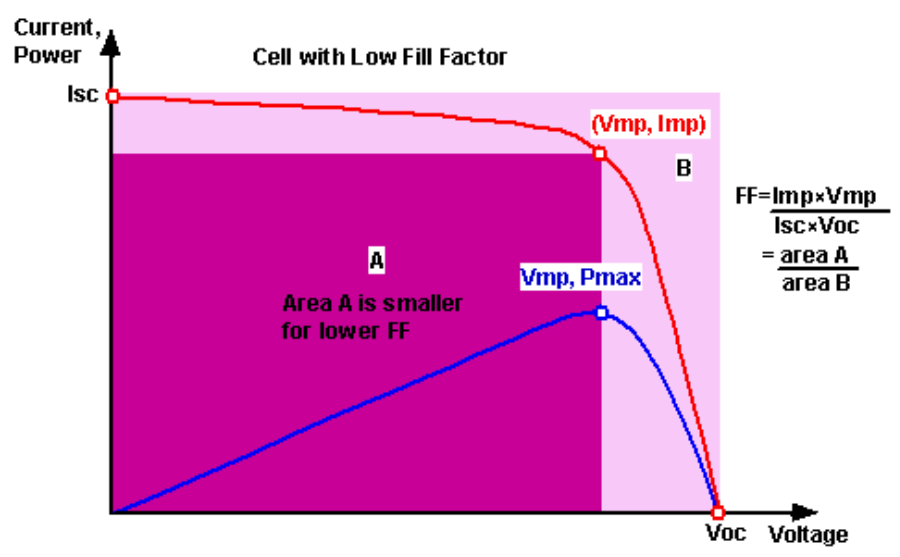

The values of different parameters of BIPV as claimed by solar cell manufacturers are mainly obtained by the quality tests done at standard testconditions (STC).

The binding quality standards for Building-Integrated Photovoltaic (BIPV) modules are the standards: EN-61646 "Thinfilm BIPV (Building-integrated Photovoltaic) modules: designer qualifications and type of approval" [8],EN-61215-2005 "Silicon (Si) crystalline terrestrial photovoltaic (PV) module: Designer qualifications and typeof approval" [9], EN61730-1 "photovoltaic (PV)module's safety qualifications - Part 1" [10], EN-61730-2 "Photovoltaic (PV) modules:design \&safety qualifications" [10] \& UL-1703 "UL-standards for safety of flat-plate Photovoltaic (PV) modules\& panels" [11]. The above mentionedstandards may be referred for further information.

\section{Current scenario of BIPVs}

\subsection{BIPV classification}

A wide range of BIPV products are available in the market, which may be classified in several different ways depending upon the criteria of characterization. This work of categorization is mainly dependent on the product specifications from thecompanies and for what other materials, the products are customized to be combined with. Based on these twoimportant factors, the building-integrated photovoltaic products or systems may beclassifiedas follows:

(i) BIPV foil products

(ii) BIPV tile products

(iii)BIPV module products

(iv) Solar cell (PV) glazing products

Other than above classifications of BIPV products, one more related category should be discussed i.e.the BuildingAttached Photovoltaic (BAPV)products, as BAPVs are very much similar to the to the BIPV systems and sometimes it may be difficult to differentiate them:

(v) BAPV products

The only major difference between the two BIPVs and BAPVs is that Building-attached photovoltaic (BAPV) products 
are observed as attachments to the buildings itself, hence they are notdirectly linked to building structure's functional aspects [3]. That is, BAPVs are different from BIPVs, because the BAPVs are not integrated into the building's envelope as like BIPVs do, thus they do not replace thetraditional/conventional building parts. Specifically, BAPVs may be referred as the attachments to the buildings, which is done after the construction work is finished.

Some of the BIPV products have extensive range of properties and features, thus it becomes more difficult to classifythem. However, in some of the cases it might be somewhat difficult to even decide whether a PV product should beconsidered as a BIPV product or BAPV product, all because ofdeficiency of information and uncertainty about how the productis going to be mounted. For detailed appraisal of the BIPV products or systems, includingthe references and contact-info, reference [5] may be referred.

\subsection{BIPV foil products}

These have an added advantage of the flexibility and arelightweight products, which areadvantageousw.r.t easier\& faster installationand prevailing weight constraints for roofs. In these foil products the PV cells are usually made from thin-film cells to uphold the flexibility feature in the foil along with their efficiency atelevated temperatures. Theyare of great use for the non-ventilated rooftop solutions. Unfortunately, at present there are only a few manufacturers of BIPV foil products available in the market whoofferreal-world weather tightsolutions. SomeBIPV foil products available to consumer in the market are given below in Table 1. They specifically have a lowfill factor because of the lower efficiency and the large solar cell resistances of thin-film cells. However, as an advantage it is always possible to alter the degree of inclination of the BIPV foil product to provideflexibility in their use.

Table 1. Specification sheet for few BIPV foil products available in the global market [5].

\begin{tabular}{|c|c|c|c|c|c|c|c|c|}
\hline Manufacturer & $\begin{array}{l}\text { Product } \\
\text { Name }\end{array}$ & $\begin{array}{l}\text { efficiency } \\
\eta \\
(\%)\end{array}$ & $\begin{array}{l}\mathrm{V}_{\mathrm{Oc}} \\
\left(\mathrm{V}_{\mathrm{olt}}\right.\end{array}$ & $\begin{array}{c}\mathrm{I}_{\mathrm{Sc}} \\
(\mathrm{Amp})\end{array}$ & $\begin{array}{l}\mathrm{P}_{\max } \\
\text { (Watt) }\end{array}$ & $\begin{array}{l}\text { Fill } \\
\text { factor } \\
(\mathrm{FF})\end{array}$ & $\begin{array}{c}\text { Area } \\
\left(\mathrm{mm}^{2}\right)\end{array}$ & $\begin{array}{l}\mathrm{P}_{\max } / \\
\text { Area } \\
\left(\mathrm{W} / \mathrm{m}^{2}\right)\end{array}$ \\
\hline \multirow[t]{2}{*}{$\begin{array}{l}\text { Alwitra } \mathrm{GmbH} \\
\text { \& Corporation }\end{array}$} & $\begin{array}{l}\text { valonV } \\
\text { olar- } 408\end{array}$ & & 138.6 & 5.1 & $\begin{array}{l}408.0 / \\
\text { module }\end{array}$ & 0.58 & $\begin{array}{l}1550 x \\
6000\end{array}$ & 42.90 \\
\hline & \begin{tabular}{|l} 
EvalonV \\
Solar- \\
136
\end{tabular} & & 46.2 & 5.1 & $\begin{array}{l}136.0 / \\
\text { module }\end{array}$ & 0.58 & $\begin{array}{l}1050 x \\
3360\end{array}$ & 38.50 \\
\hline
\end{tabular}

\subsection{BIPV tile products}

Basically, BIPV tile products are the roofing tiles which may shield the entire rooftop or a part of the rooftop and act as the replacement for conventional/traditional tiles used on the rooftops.In view of their structure, they are side-by-side arranged PV modules with samephysical look and properties like of standard roof tiles and act as asubstitute to thetraditional roof tiles, thus enables the easy retro-fitting of roofs. The tile shape and cell type differs with the manufacturer.Fewof the tile productslook like curved ceramic tiles but they have a drawback of lesser effective area because of its curvy surface, but on the other side they are more aesthetic and hence preferred for looks and decorative finishing. Some examples of BIPVtile products available to the customer in the market are given below in Table 2.

Table 2. Specification sheet of few BIPV tile products available in the global market [5].

\begin{tabular}{|l|l|l|l|l|l|l|l|l|}
\hline Manufacturer & $\begin{array}{l}\text { roduct } \\
\text { Name }\end{array}$ & $\begin{array}{l}\text { efficienc } \\
\eta \\
(\%)\end{array}$ & $\begin{array}{l}\mathrm{V}_{\text {Oc }} \\
(\mathrm{Volt})\end{array}$ & $\begin{array}{c}\mathrm{I}_{\mathrm{Sc}} \\
(\mathrm{Amp})\end{array}$ & $\begin{array}{l}\mathrm{P}_{\max } \\
(\text { Watt })\end{array}$ & $\begin{array}{l}\text { Fill } \\
\text { factor } \\
(\mathrm{FF})\end{array}$ & $\begin{array}{l}\text { Area } \\
\left(\mathrm{mm}^{2}\right)\end{array}$ & $\begin{array}{l}\mathrm{P}_{\max } / \\
\text { Area } \\
\left(\mathrm{W} / \mathrm{m}^{2}\right)\end{array}$ \\
\hline SRS Energy & $\begin{array}{l}\text { Solé } \\
\text { Powertile }\end{array}$ & & 6.30 & 4.6 & $\begin{array}{l}15.75 / \\
\text { module }\end{array}$ & 0.54 & $\begin{array}{l}868 \mathrm{x} \\
457.2\end{array}$ & 39.70 \\
\hline $\begin{array}{l}\text { Solardachstei } \\
\text { n }\end{array}$ & $\begin{array}{l}\text { STEPdesig } \\
\mathrm{n}\end{array}$ & & 23.75 & 2.40 & $1.36 /$ cell & 0.76 & $\begin{array}{l}100 \times 100 \\
8 \text { units }\end{array}$ & 136 \\
\hline Solar Century & C-21e Tile & $20 /$ cell & 12.0 & 5.55 & $\begin{array}{l}52 / \\
\text { module }\end{array}$ & 0.78 & $\begin{array}{l}1221 \mathrm{x} \\
420\end{array}$ & 101.50 \\
\hline Lumeta & $\begin{array}{l}\text { Solar Flat } \\
\text { Tile }\end{array}$ & & 7.41 & 5.20 & $\begin{array}{l}28 / \\
\text { module }\end{array}$ & 0.73 & $432 \times 905$ & 71.60 \\
\hline
\end{tabular}

The BIPV tile products from top manufacturers Solardachstein, Solar Century and Lumeta provide the highest FF (fill factors) which indicates their high efficiency. In fact, Solar Century offers an efficiency of 20 percent/ cell fortheir C-21e Tile and is more area effective. Further, the available design concept of the of the manufacturers like SoléPowertile and the STEPdesign is very much similar to the standard roof tiles, hence, theymay replace several standard roof tiles. But, in these the PV module has an integrated panel of monocrystalline or polycrystallinecells. i.e., portions of the modules are not externally covered with PV cells, hence the areaefficiency is low. The C-21e Tile from Solar Century has more active area than the any other products since monocrystalline Si (Silicon) cells shield the complete module area, and has compatibility witha diverse range of tiles and slates. SoléPowertile from SRS-Energy hasskeleton very much similar to standard rooftop tiles. 


\subsection{BIPV module products}

The BIPV modules are the solar products that look very much similar to traditional/conventional photovoltaic modules. But in case of BIPV modules, we have an advantage of having dual functionality

i.e. together with electricity generation, they also provide theweather tight solutions. There are two types of BIPV moduleproducts, one which may replace several different types of roofing materialsi.e. they are not manufacturer specific while second includes those which may fit only with a specific roof solution made by itsown manufacturer. Further, the mounting systems of the BIPV modules makes their installation easier and hassle free.There are variety ofproducts in the market out of which some are promoted as BIPV productsirrespective of the fact that they do not function as weather skins, while other Building-Integrated Photovoltaic (BIPV) products do not provide any information about how they have to be mounted which leads to obscurity whether they are BIPVs or BAPVs.Some of the BIPV module products availablein the market are given below in Table 3.

Table 3: Specification sheet of few BIPV module products available in the global market [5].

\begin{tabular}{|c|c|c|c|c|c|c|c|c|}
\hline Manufacturer & $\begin{array}{l}\text { Product } \\
\text { Name }\end{array}$ & $\begin{array}{l}\text { efficiency } \\
\eta \\
(\%)\end{array}$ & $\begin{array}{c}\mathrm{V}_{\mathrm{Oc}} \\
\text { (Volt) }\end{array}$ & $\begin{array}{c}\mathrm{I}_{\mathrm{Sc}} \\
\text { (Amp) }\end{array}$ & $\begin{array}{c}\mathrm{P}_{\max } \\
(\text { Watt })\end{array}$ & $\begin{array}{l}\text { Fill } \\
\text { factor } \\
(\mathrm{FF})\end{array}$ & $\begin{array}{c}\text { Area } \\
\left(\mathrm{mm}^{2}\right)\end{array}$ & $\begin{array}{l}\max / \text { Area } \\
\left(\mathrm{W} / \mathrm{m}^{2}\right)\end{array}$ \\
\hline \begin{tabular}{|l} 
Abakus \\
Solar- AG
\end{tabular} & $\begin{array}{l}\text { Peak-on } \\
\text { P235-60 }\end{array}$ & 14.60 & 37.21 & 8.48 & 235 & 0.74 & $\begin{array}{l}1630 \mathrm{x} \\
1000\end{array}$ & 144.20 \\
\hline Creaton-AG & $\begin{array}{l}\text { Creaton- } \\
\text { Solesia }\end{array}$ & & 13.86 & 8.46 & $\begin{array}{l}90 / \text { mod } \\
\text { ule }\end{array}$ & 0.77 & $1778 \times 355$ & 142.60 \\
\hline Suntech & $\begin{array}{l}\text { MSZ- } \\
\text { 190JD }\end{array}$ & & 45.20 & 5.62 & $\begin{array}{l}190 / \mathrm{mo} \\
\text { dule }\end{array}$ & 0.75 & $\begin{array}{l}1641 \mathrm{x} \\
834.50\end{array}$ & 139 \\
\hline Solar Century & $\begin{array}{l}\text { C-21e } \\
\text { slate }\end{array}$ & 20/cell & 12.0 & 5.55 & 52 & 0.78 & $1174 \times 318$ & 139.31 \\
\hline
\end{tabular}

\subsection{Solar cell (PV) glazing products}

Building-Integrated photovoltaic products when used as solar cell (PV) glazing products offer abundant variety of choices for building windows, tiled or glassed frontages and roofing, Different transparencies and colors can providedifferent aestheticalresults. Someof the solar cell (PV) glazing product available to the customer in the market are given below in Table 4. The solar cell (PV) glazing modules serves dual functions i.e. they transmit daylight and also serve as water and sun protection inside the building. The optimum gapbetween the solar cells is normally $3-50 \mathrm{~mm}$ in solar cell (PV) glazing products which depends on desired transparency and the amount ofelectricity to be produced. The available gap between the solar cells transmits diffused sunlight in the daytime. Therefore, both natural lighting and shading are provided along with electricity production.

The solar cell (PV) glazing product's manufacturers generally provide customized products aboutthe shape, cell material, color and different transparency level, i.e. the available gap between the cells.

Generally, the transparency of the solar cells (PVs)falls in the range of $16 \%$ to $41 \%$ for different Vidursolar models, while it has value of $25 \%$ for the Abakus Solar-AG Peak in his P210-60 item model. The distinctive models from Sapa Building System utilizes either formless, polycrystalline or monocrystalline cells with various cell detachments.

Table 4. Specification sheetoffew solar cell (PV) glazing products available in the global market [5].

\begin{tabular}{|c|c|c|c|c|c|c|c|c|}
\hline Manufacturer & product Name & $\begin{array}{l}\text { efficiency } \eta \\
(\%)\end{array}$ & $\begin{array}{l}\mathrm{V}_{\mathrm{Oc}} \\
\text { (Volt }\end{array}$ & $\begin{array}{c}\mathrm{I}_{\mathrm{Sc}} \\
\text { (Amp) }\end{array}$ & $\begin{array}{c}P_{\max } \\
\text { (Watt) }\end{array}$ & $\begin{array}{l}\text { Fill } \\
\text { facto } r \\
\text { (FF) }\end{array}$ & $\begin{array}{c}\text { Area } \\
\left(\mathrm{mm}^{2}\right)\end{array}$ & $\begin{array}{l}\max / \\
\left(\mathrm{W} / \mathrm{m}^{2}\right)\end{array}$ \\
\hline Vidursolar & \begin{tabular}{|l|l|}
$\mathrm{FV}-\mathrm{VS} 16$ \\
$\mathrm{C} 36-\mathrm{P} 120$ \\
\end{tabular} & 21.60 & 7.63 & & & & $\begin{array}{l}1600 x \\
720\end{array}$ & \\
\hline $\begin{array}{l}\text { Glaswerke } \\
\text { Arnold GmbH } \\
\text { \&Corporation }\end{array}$ & $\begin{array}{l}\text { Voltarlux- } \\
\text { ASI-TMono } \\
\text { 4-fach }\end{array}$ & & 93 & 1.97 & $\begin{array}{l}100 / \\
\text { module }\end{array}$ & 0.55 & $\begin{array}{l}2358 x \\
1027\end{array}$ & 41.3 \\
\hline Schott Solar & $\begin{array}{l}\text { ASI-THRU- } \\
4 \mathrm{IO}\end{array}$ & 6.0 & 111 & 2.21 & 189 & 0.77 & $\begin{array}{l}1123 x \\
2620\end{array}$ & 64.72 \\
\hline \multirow{3}{*}{\begin{tabular}{|l|} 
Sapa- \\
integrated \\
Building \\
System
\end{tabular}} & $\begin{array}{l}\text { Amorphous } \\
\text { ilicon(Si) thin } \\
\text { film }\end{array}$ & $5.0 /$ cell & & & $32 /$ cell & & \begin{tabular}{|l|}
$576 \mathrm{x}$ \\
976 \\
cell \\
\end{tabular} & 50 \\
\hline & $\begin{array}{c}\text { Poly- } \\
\text { crystalline }\end{array}$ & $16.0 /$ cell & & & $\begin{array}{l}1.46- \\
3.85 \\
\text { cell }\end{array}$ & & $\begin{array}{l}156 \mathrm{x} \\
156 \\
\text { /cell }\end{array}$ & 120 \\
\hline & $\begin{array}{l}\text { Mono- } \\
\text { crystalline } \\
\text { Highlyeffici } \\
\text { ent }\end{array}$ & 22.0/cell & & & $\begin{array}{l}2.91- \\
3.11 \\
\text { /cell }\end{array}$ & & $\begin{array}{l}125 \mathrm{x} \\
125 \\
\text { /cell }\end{array}$ & 155 \\
\hline
\end{tabular}




\subsection{BAPV products}

The Building Attached Photovoltaics (BAPVs) are the products that add on rather than integrated in the rooftop or frontage like BIPV products. They are extra attachments to the building and installed after the construction of building is completed. TheBAPV solar products are not the main focus of this research work, but because of their similarities with BIPV products, it would be more interesting to look briefly at some of them. The Uni-Solar laminate (BAPV) available in the market have good flexibility, thus makes it easier to join with other building materials. Some other examples of BAPVproducts available to the customer in the market are given below in Table $\mathbf{5}$.

Table 5. Specification sheet of few of the BAPV products available in the global market [5].

\begin{tabular}{|l|l|l|l|l|l|l|l|l|}
\hline Manufacturer & $\begin{array}{l}\text { Product } \\
\text { Name }\end{array}$ & $\begin{array}{l}\text { efficiency } \\
(\%)\end{array}$ & $\begin{array}{l}\text { Voc } \\
\text { Volt })\end{array}$ & $\begin{array}{l}\mathrm{I}_{\mathrm{Sc}} \\
(\mathrm{Amp})\end{array}$ & $\begin{array}{l}\text { Pmax } \\
(\text { Watt })\end{array}$ & $\begin{array}{l}\text { Fill } \\
\text { factor } \\
(\mathrm{FF})\end{array}$ & $\begin{array}{l}\text { Area } \\
\left(\mathrm{mm}^{2}\right)\end{array}$ & $\begin{array}{l}\mathrm{P}_{\max } / \\
\text { Area } \\
\left(\mathrm{W} / \mathrm{m}^{2}\right)\end{array}$ \\
\hline Hauptsitz & $\begin{array}{l}\text { SunPower } \\
220 \text { Solar } \\
\text { Panel }\end{array}$ & 17.70 & 48.60 & 5.75 & & & $\begin{array}{l}1559 \mathrm{x} \\
798\end{array}$ & \\
\hline Uni-Solar & PVL-68 & & 23.10 & 5.10 & $68 /$ module & 0.58 & $\begin{array}{l}2849 \mathrm{x} \\
394\end{array}$ & 60.60 \\
\cline { 2 - 9 } & PVL-144 & & 46.20 & 5.30 & $144 /$ module & 0.59 & $\begin{array}{l}5486 \mathrm{x} \\
394\end{array}$ & 66.60 \\
\hline Isofoton & ISF-240 & 14.50 & 37.10 & 8.45 & 240 & 0.77 & $\begin{array}{l}1667 \mathrm{x} \\
994\end{array}$ & 144.80 \\
\hline
\end{tabular}

\section{Economical aspects of BIPVs}

As per the report of consulting firm Nano-Markets,New York [12], the global market for BIPVs is estimated to grow from $\$ 1.8 \cdot 109$ in 2009 , to $\$ 8.7 \cdot 109$ in 2016 . Further, Nano-Markets state that CopperIndium Gallium Selenide solar power cells will account for $17 \%$ of the BIPV market in 2016and polysilicon-based BIPVs will drop from $75 \%$ of the market to $33 \%$ by 2016 in terms of volume [12]. As PV panels requires a large installation area, the associated financial challenge may be best countered byspace-saving technologies like BIPVs [13]. BIPV systems are cheaper than other traditional/conventional PV systems that need separate and dedicated mounting systems. Further, Integration of photovoltaicproducts into building parts such as rooftops, windows, sunshades and glassed frontages gives the opportunity of cost saving by substitutingcommon building materials with BIPVs at peripheral costs [6]. When BIPVs usedas a covering material are compared to steel, glass orother more traditional/conventional covering materials, they seem to be much economical because of their low running and maintenance cost,but installing BIPV products adds a marginal extra cost of 2-5\% ofthe complete construction costs of a commercial building which later on gets balanced by the lower running and maintenance cost [14]. Also, this marginal installation andoperation cost of the BIPV products/systems might be minimized by selling the surplus electricity to a regional power distribution company and may become a profit business.[15].

Meanwhile, the price of a PV system is on decline with the improvement of technology advancement and increasing cutthroat competition in the global market,which has resulted into a lesser price per kW installed PV system [16], which is avital part of the development for makinginstallation and building integration of PV modulesmore profitable without government subsidies. To work out the energy payback time, the embodied energy of the system should be calculable [15]. For detailed knowledge of theenergy- payback time reference [17] may be referred.Research and development work in the area of photovoltaic (PV) cells \&modules and improvement/advancements in their technologies may have an even strongerimpact on the coming future of BIPVs.

\section{Conclusions}

Today, theexisting building-integrated photovoltaic products in the market,offer an extensive range of integration of photovoltaic (PV) products or systems into buildings and their roofing\& frontages. The research anddevelopment workis continued in both PV and BIPV materials and advancement in technologies will definitelyproducebetter BIPVsolutions along with good cost economics in the adjacent future. The increased efficiency of solar cell, reduction in productioncosts and improved building integration will bang the coming future of solar BIPVs \& BAPVs. Further, there is a need of new and innovative solutions in the field of BIPVs whichmay cut costs and increase efficiency of BIPV products.

\section{Acknowledgement}

This exploration/research work has been finished under the guidance and support of Dr. J.P. Kesari, Former AICTE Director, Associate Professor, Delhi Technological University (formerly Delhi College Engineering).

\section{References}

[1] Dr. J.P Kesari. Empowering India with Green Energy Technology, paper presented in 53rd National Convention of Indian Institution of Industrial Engineering and National conference on India as a Technology Hub, (Dec. 16-17), 2011.

[2] Kesari J.P. Solar Thermal Power Generation in India: An overview of recent policies under National Solar Mission, Proceedings of the National Conference on Management of Technologies for Advancing Rural India, SDCOE at 
Muzaffarnagarfeb.( 5-6), 2011.

[3] Y. Huang,Z. Wu,C. Peng, Building-integrated photovoltaics(BIPVs) in architectural design in China, Energy and Buildings43 (2011) 3592-3598.

[4] S. Strong, Building-Integrated Photovoltaics (BIPVs), Whole Building Design Guide, <http://www.wbdg.org/resources/bipv.php>, June 9, 2010.

[5] B.P. Jelle, H.D. Røkenesand C. Breivik, BIPVs: A state-of-the-art review and futureresearch opportunities, Solar Energy Materials and Solar Cells, doi: 10.1016/j.solmat.2011.12.016, in press, 2012.

[6] T.K. Mallick, P.C. Eames, B. Norton,S.J. McCormack,M.J. Huang,Y.G. Yohanis and J.D. Mondol,Enhancing theperformance of BIPVs, Solar Energy 85 (2011) 1629-1664.

[7] A.G. Hestnes, Building-integration of solar energy systems, Solar Energy 67 (2000) 181-187.

[8] European Committee for Electro-TechnicalStandardization, Thin-film Terrestrial Photovoltaic (PV) Modules DesignQualification and Type Approval, EN 61646, European Standard, 2008.

[9] European Committee for Electro-TechnicalStandardization, Crystalline Silicon Terrestrial Photovoltaic (PV) Modules - DesignQualification and Type Approval, EN 61215, European Standard, 2005.

[10] European Committee for Electro-TechnicalStandardization, Photovoltaic (PV) Module Safety Qualification - Part 1\& Part 2: Requirements for Construction, EN 61730-1\&EN 61730-2, European Standard, 2007.

[11] Underwriters Laboratories Inc., UL Standard for Safety Flat-Plate Photovoltaic Modules and Panels, UL $1703,2002$.

[12] Dow,R. Coons: Solar shingles could generate \$5 billion by 2015, Chemical Week 171 (2009) 9.

[13] S.N. Mandal,D. Paul, S.R. Bhadra and D. Mukherjee Chaudhuri, Optimisation of significant insolation distributionparameters - A new approach towards BIPV system design, Renewable Energy 35 (2010) 2182-2191.

[14] P. Eiffert, Guidelines for the economic evaluation of building-integrated photovoltaic (BIPV) power systems, NREL/TP-550-31977,2003.

[15] IEA-PVPS, Grid-connected power systems: Summary of IEA/PVPS Task V activities from 1993 to 1998, T5-03, 1999.

[16] M. Elnimeiriand H. Sozer, Critical factors in reducing the cost of building-integrated photovoltaic (BIPV) systems, Architectural Science Review-50 (2007) 115-121.

[17] G.P. Hammond, C.I. Jones, A.B. Winnett andH.A. Harajli, Whole systems appraisal of a UK buildingintegratedphotovoltaic (BIPV) system: Energy, environmental, and economic evaluations, Energy Policy- 40 (2012) 219-230. 